\title{
SANTOS PATRONOS EN LOS ANDES. IMAGEN, SÍMBOLO Y RITUAL EN LAS FIESTAS RELIGIOSAS DEL MUNDO ANDINO COLONIAL (SIGLOS XVI - XVII)
}

In the Andes Patron Saints. Image, symbol and ritual in the religious festivals of the andean World Colonial (XVI - XVII)

\author{
Alberto Díaz Araya* \\ Luis Galdames Rosas \\ Wilson Muñoz Henriquez
}

\section{Resumen}

La celebración de fiestas en honor a los santos patronos de las comunidades andinas es una de las manifestaciones de religiosidad más extendidas desde la Colonia. Más allá de entenderla como una manifestación en continuidad directa con las prácticas cúlticas del Tawantinsuyo o la ritualidad católica española, consideramos que esta festividad es un fenómeno emergente que debe ser analizado en su especificidad. El objetivo de este artículo es analizar la figura del santo y su eficacia simbólico-ritual en la fiesta patronal andina desarrollada durante el periodo colonial (XVI-XVII). A partir del análisis de una serie de crónicas coloniales, intentaremos mostrar que las especificidades rituales de la fiesta y de la operación del santo como símbolo icónico dominante permiten comprender su eficacia simbólica, así como también la co-existencia de diversas interpretaciones y escenificaciones rituales que darían cuenta de la agencialidad ritual de la comunidad.

Palabras clave: Fiesta patronal, ritual, santo, símbolo, icono.

\section{Abstract}

The celebration of festivities in honor of the patron saints of the Andean communities is one of the most widespread manifestations of religiosity from the Colony. Beyond understood as a manifestation in direct continuity with the cultic practices of the Catholic ritual Tawantinsuyo or Spanish, we believe that this festival is an emerging phenomenon that must be analyzed in its specificity. The aim of this paper is to analyze the figure of the saint and their efficacy in symbolic ritual Andean fiesta developed during the colonial period (XVI-XVII). From the analysis of a series of colonial chronicles, try to show that the specific rituals of celebration and operation saint as provide insight dominant iconic symbol symbolic effectiveness, as well as the co-existence of different interpretations and stagings rituals give account of agency community ritual.

Key words: Party bosses, ritual, holy symbol, icon.

\footnotetext{
${ }^{1}$ Artículo resultado del Proyecto FONDECYT $\mathrm{N}^{\circ} 1120530$ y del Proyecto de Investigación Mayor de Ciencia y Tecnología de la Universidad de Tarapacá, № 5731-12. Asimismo, se agradece el apoyo del Convenio de Desempeño Universidad de Tarapacá-Mineduc.
} 


\section{INTRODUCCIÓN}

Con la llegada en el siglo XVI de los españoles a la América andina comienza la transformación de los sistemas sociales y culturales que las poblaciones indígenas habían cimentado durante los siglos anteriores. Dentro de los ámbitos que experimentaron mayores reconfiguraciones destaca el de las creencias y prácticas cúlticas a las deidades nativas. En tal sentido, la evangelización en diferentes contextos y programas catequéticos jugó un rol clave en la construcción de una arquitectura religiosa que colisionó con el fervor a las waka, el culto a los antepasados o las ceremonias conducidas por "hechiceros" indígenas que fueron significados como idólatras, tal como sugerentemente ha propuesto Millones (2005).

No obstante, más allá de la catequesis que la Iglesia y los misioneros instrumentalizaron, la población hispana, entre soldados iletrados, trajo al continente una cultura religiosa popular que sobrepasaba con creces los férreos dogmas eclesiales. El culto a las imágenes de Cristo, la Virgen, la celebración de las fiestas patronales, el Corpus Christi, las Cruces de Mayo y las procesiones formaban parte de un acervo religioso público que rápidamente fue recepcionado por los indios desde una praxis agencial, dando como fruto una propia identidad religiosa católica (Albó, 2002; Marzal, 2002).

Así, al igual como en España, las festividades a los santos ha sido una de las manifestaciones de religiosidad más extendidas en toda la cordillera andina. La literatura que ha intentado describir, caracterizar y comprender el éxito de estas prácticas se encuentra relativamente dividida desde la conceptualización misma del fenómeno devocional. Mientras que, por un lado, estas fiestas se comprenden como rituales comunitarios impuestos por la Iglesia; por otro lado, existen planteamientos que intentan subrayar la idea de la continuidad de los cultos propios del Tawantinsuyo en un contexto religioso colonial. Evidentemente, hay un espectro de posiciones ubicadas entre ambos polos que matizan estas explicaciones. Sin embargo, una de las dimensiones poco exploradas ha sido el análisis del ámbito simbólico y ritual en sí mismo, un terreno complejo donde se manifiesta la especificidad sociocultural, por lo que su exploración constituye un desafío doblemente relevante.

Este artículo se detiene a examinar la figura del santo y su eficacia simbólico-ritual en las celebraciones patronales durante la Colonia (siglos XVI y XVII). Para ello analizaremos una serie de dispositivos eclesiásticos y crónicas que describen la tradición devocional hispánica practicada en los Andes.

Desde un enfoque interpretativo, presuponemos que si bien existe una cierta homología estructural entre las prácticas desplegadas en el Tawantinsuyo y la ritualidad católica, lo que habría facilitado la recepción de la tradición religiosa, también existen importantes diferencias entre ambas. Bajo este supuesto, conjeturamos que en el caso de la fiesta patronal es la propia naturaleza simbólica de la figura del santo la que ha asegurado su eficacia 
simbólico-ritual, permitiendo la coexistencia de una diversidad de significados e inventivas populares escenificadas en las manifestaciones cúlticas en torno a las imágenes, como parte integrante del repertorio de la agencia ritual andina. Dicho sea de paso, las celebraciones a los santos se acercan más a un fenómeno sociorreligioso emergente, que a una práctica de continuidad con las tradiciones que operaron como condición de su posibilidad.

\section{ENTRE FIESTAS, SANTOS E INDÍGENAS}

La cultura devocional de los españoles trajo a América una experiencia que claramente desbordaba el canon eclesiástico imperante hacia el siglo XVI, reproduciendo en los Andes manifestaciones populares que se remontaban al medioevo europeo (Bajtin, 2003). El culto a las imágenes, las fiestas patronales, carnavales, las danzas en homenaje al Corpus y las fastuosas procesiones sostenidas por las cofradías de los conquistadores fueron representaciones religiosas rápidamente reconfiguradas por las poblaciones andinas (Díaz, 2011; Estenssoro 2001).

A nuestro entender, las regulaciones de la evangelización expresadas en los Concilios fueron dispositivos que contribuyeron a la recepción de la cultura religiosa hispana a nivel comunitario. De hecho, el Primer Concilio de Lima (1551) intentó regimentar en un solo formato la catequesis de las nuevas almas, disponiéndose que los naturales fueran evangelizados en lengua vernácula y administrando desde doctrinas o parroquias los sacramentos del bautismo, la penitencia y el matrimonio. Sobre estos tópicos, tempranamente la Curia estableció que

Declaramos, las fiestas que éstos han de guardar de precepto y son obligados a oír misa son las siguientes. Todos los domingos del año, la fiesta de la Circumcision, la fiesta de los Reyes, los primeros días de las tres pascuas, la fiesta de la Ascensión de Cristo, la de Corpus Christi y las cuatro fiestas de nuesra Señora, la Natividad, la Anunciación, Purificación y Asunción y la fiesta de Sant Pedro y Sant Pablo. Y los ayunos que de precpto son obligados a guardar los que fueren de edad de derecho, son las vigilias de la Natividad y Resurreción y todos los viernes de la cuaresma (Vargas Ugarte, 1951:18-19).

Esta regulación grafica la configuración del calendario litúrgico, instituyendo las celebraciones que rápidamente se transformaron en dispositivos que pugnaron por establecer un nuevo orden sociorreligioso colonial. De hecho, la dimensión ritual en este proyecto se expresa claramente en una de las principales consecuencias decretadas: la eucaristía pasaba a convertirse en el epicentro donde debía irradiar la fe católica y el adoctrinamiento de los indios.

Para el Segundo Concilio (1565) se intentó contextualizar a la realidad del Perú los dogmas del Concilio de Trento (1564), uniformando los preceptos rectores de la Iglesia. Esta asamblea de prelados advirtió la necesidad de emprender procesos de catequesis en lengua aborigen, para lo cual los sacerdotes debían 


\section{Alberto Díaz, Luis Galdames, Wilson Muñoz}

instruirse en los lexicones de aymara y/o quechua, respectivamente. Se insistió también en que la evangelización se concentrara en territorios sujetos a doctrinas, siguiendo los preceptos redaccionales que proyectaba la Corona. Aunque a los indios se les prohibió consagrarse como sacerdotes, debían acudir a misa regularmente, asistir a catequesis los días miércoles y viernes, y guardar los días de fiestas (que no eran pocos), momento en que los curas debían administrar piadosamente los sacramentos y la doctrina. También debían participar en las fiestas del calendario católico, realizando actividades como la ornamentación de los templos y retablos, o acompañando con música y coros las eucaristías y procesiones. Además, se exhortaba a los naturales a que dejaran el culto a los antepasados, a las wakas, apachetas o adoratorios, so pena de castigos.

Entre los diferentes preceptos conciliares, se volverá a insistir en la participación obligatoria de los indios en las de múltiples festividades, como parte de la dimensión ritual en la evangelización. Sin perjuicio de lo anterior, la mera participación no aseguraba la total ni inmediata asimilación de los mensajes doctrinales entregados bajo los códigos eclesiales. De hecho el rito, por su propia estructura simbólica centrada en la actuación o representación, posibilitaría la emergencia de variadas lecturas locales, mecanismo que en cierta forma permitiría comprender el éxito de estas prácticas.

Una muestra de la dimensión ritual como ámbito de reproducción de la fe católica se evidencia en el tratamiento que recibieron los taki (cantos y danzas indígenas practicadas durante el Tawantinsuyu), por parte de los misioneros. Como advertimos, si bien se exhortó a los naturales a abandonar el culto a sus dioses, el Segundo Concilio tuvo un tratamiento especial con esta manifestación (Estensoro, 1992). La "política de sustitución" en el tratamiento de los taki es ciertamente reveladora, pues evidencia la relectura en clave local que intentaba hacer la Iglesia del mensaje evangelizador. De alguna forma, si en estricto rigor aquella performance coreográfica y los cánticos indígenas fervorosos como los taki no hubiesen tenido algún sentido para la mirada clerical, quizá su prohibición no hubiese tardado en manifestarse. La permisividad de su celebración, siempre que se transformara en una danza y cántico ritual "a favor de Dios", evidencia al parecer una cierta homología estructural entre la práctica nativa y la católica, y no únicamente el despliegue de intereses estratégicos para el proyecto catequético, aunque también estuvieran presentes.

No obstante, esta inferencia no debe velar la existencia de asimetrías y diferencias desarrolladas en el seno de esta homología genérica. Pese a la aceptación de los taki, las celebraciones de estas y otras ceremonias estaban reglamentadas y debían ser vigiladas (Millones, 2007). Así, en todas las festividades, los clérigos debían disciplinarlas y evitar el consumo de chicha y las borracheras, para lo cual se exigía que "los Curas no permitan que los indios con pretexto de fiesta se exedan en comidas y bebidas fuertes" (Vargas Ugarte, 1951:65). 
En el año 1582, el Tercer Concilio generó el documento "Doctrina Cristiana y Catecismo para la instrucción de los indios", obra que debía ser referente para el adoctrinamiento de los indígenas, evitando interpretaciones o propuestas equívocas de los cánones. Entre las disposiciones se pauteaba que los curas doctrineros debían instruir no sólo en la fe, sino también en la enseñanza de la escritura y la lectura, además de la instrucción en las artes musicales para el acompañamiento de los oficios religiosos. El aprendizaje del catecismo en diferentes formatos fue una estrategia que los misioneros utilizaron en los Andes, enseñando

algunos cantares de cosas deuotas y la mesma doctrina xpiana, y estaban ellos tan diestros y aficionados a esta manera de canto, que andaban siempre de noche y de día cantándolos por las calles y en sus cassas, y como es costumbre q. la gente popular, especialmente las mugeres, aprenden los cantares q. vienen de nuevo de cualquier materia que sean... como oyan estos cantares a los muchachos yvanlos aprendiendo en sus cassas, de manera $\mathrm{q}$. estando las mugeres con sus almohadillas y los oficiales en sus obras, cantaban las canciones (Mateos, 1944:202).

Además, se realizaban procesiones por las aldeas buscando:

honrarlos (a los indios) conforme a la calidad y oficio y en las conversaciones particulares, contar vidas de sanctos y tratar cosa de virtud; componerles letras en su lengua a lo divino y hacer que las canten ante ellos, para que se olviden de los cantares antiguos, y por vía de la música se les encajone la declaración de los Artículos y Mandamientos y Sacramentos y Obras de Misericordia (Anónimo, 1968:383).

La enseñanza de la música como un dispositivo catequético no es menor. Utilizar una manifestación asentada en la cultura andina, a través de la cual se desarrollaba también la tradición católica, evidencia otra de las estrategias de adoctrinamiento, cuyo relativo éxito aparece reflejado en la supuesta afición que generaron las destrezas artísticas entre los indios.

Recordemos que las ceremonias ocuparon un lugar central en las catequesis de dominicos, franciscanos y/o agustinos, quienes no sólo utilizaron las cartillas que replicaban la doctrina en el sur andino (incluido el actual norte chileno), sino que difundieron el culto a la eucaristía, a las cruces y a la Virgen (Heras 1990). Siguiendo este entramado, las palabras del franciscano Jerónimo de Oré evidencian un fenómeno clave para comprender el desarrollo de las festividades, pues consideraba:

muy justo y conveniente que en todas las iglesias de los indios haya imagen de esta gloriosa Virgen, y si pudiera ser, tenga altar o capilla particular, para que con más devoción acudan los indios a invocarla en todas sus necesidades (...) las fiestas principales de Nuestra Señora sean celebradas con solemnes vísperas, misa, procesión y sermón, y si no hubiera sermón, por la solemnidad de aquel día se diga catecismo (Oré, 1598:57). 
Una imagen y un altar en los Andes. Este deseo de Oré evidencia el poder que ofrece la operación de los símbolos sagrados; su eficacia simbólica en el rito. De hecho, el deseo del misionero por ubicar las imágenes en altares o capillas delata el carácter cúltico que acompañaba a este símbolo religioso: vísperas, misa, procesión y sermón desplegados en torno a la imagen del santo lo evidencian.

La imagen de los santos (incluidas las de Cristo y la Virgen) se convierte, o debiera convertirse, en el centro neurálgico de la devoción indígena, constituyéndose así en el polo de atención de la interacción ritual. De allí entonces que se comportara no como símbolo aislado, el cual a través de la manifestación de su imagen de patrono convertida en significante, remite a la invisibilidad de su si no que estas imágenes operan más bien como verdaderos iconos, en tanto la representación de la realidad cristalizada en la imaginería es simultáneamente la realidad en sí misma que representa: es el santo, la Virgen o el Cristo encarnado. Es por ello que las imágenes pueden suscitar una mayor efervescencia devocional, pues la invocación, aunque mediada por la imagen, se entrega a la realidad sacra en sí misma. En otras palabras, la imagen cúltica del santo católico no sólo refiere a, sino que simultáneamente es la realidad sagrada.

Lo interesante en términos rituales es que las celebraciones colectivas en torno a las imágenes fueron actividades religiosas que sistemáticamente se reprodujeron en todas las comarcas andinas, atrayendo a una gran cantidad de indios congregados para la Semana Santa o alguna otra festividad. Por ejemplo:

el miércoles, jueves y viernes santo salen cinco procesiones de diversas advocaciones de penitentes. La una se dice de los Nazarenos, que sale de Santo Domingo el miércoles en la noche, con mucho número de penitentes con sus túnicas moradas y cruces en los hombros (Cobo, 1653:456).

En su contenido estético, la siguiente imagen encierra retazos de lo que estamos exponiendo:

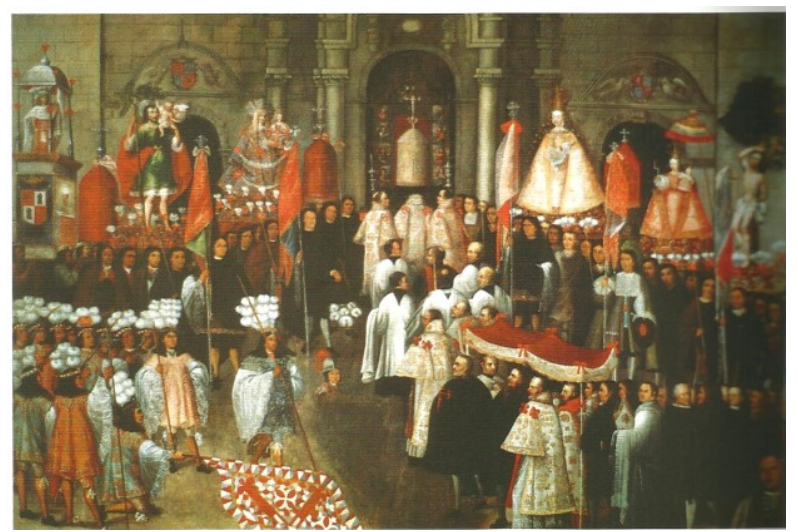

La procesión de Corpus llega a las puertas de la catedral de Cuzco. Atribuido a Basilio de Santa Cruz, Museo Virreinal, Cuzco. Fuente: Gisbert (2007:40). 
De acuerdo con Marzal (2002), durante el Tawantinsuyu el calendario festivo estaba articulado en gran medida por el ciclo agrícola o la veneración de sus deidades fundantes. Para los siglos XVI-XVII la Iglesia manejaba dos tiempos o ciclos del culto claramente diferenciados. Nos referimos al ciclo litúrgico y al ciclo santoral. El primero da cuenta de la vida de Cristo para la redención de los hombres y posee cinco tiempos litúrgicos: arranca en el mes de diciembre con el Adviento, seguido por la Navidad, la Cuaresma, la Pascua y Pentecostés. Su principal objetivo era celebrar la historia de la salvación mediante el desarrollo de ceremonias que involucraban a toda la feligresía redimida ante el Señor (Marzal, 1983).

Por su parte, la celebración a los santos correspondía al ciclo santoral. La conmemoración del nacimiento o muerte del santo vinculada a su hagiografía, según correspondiera, tenía como propósito conseguir la intercesión del santo ante Dios, siendo un personaje que por sus virtudes evangélicas debía ser imitado por la cristiandad. De hecho, las aldeas y pueblos fueron consagrados a un santo protector o patrono en toda la cristiandad (Millones, 2005).

Otra muestra clara de la activa resemantización de la tradición europea y de parte de la población indígena queda de manifiesto en la reconfiguración simbólica que sufrieron muchas figuras arquetípicas de los santos patronos católicos en el imaginario, religioso andino. Por ejemplo, San Santiago, reconocido en España como "Santiago mata moros", en los Andes fue reinterpretado y reconocido rápidamente como "Santiago mata indios", tal como puede apreciarse en las siguientes imágenes:

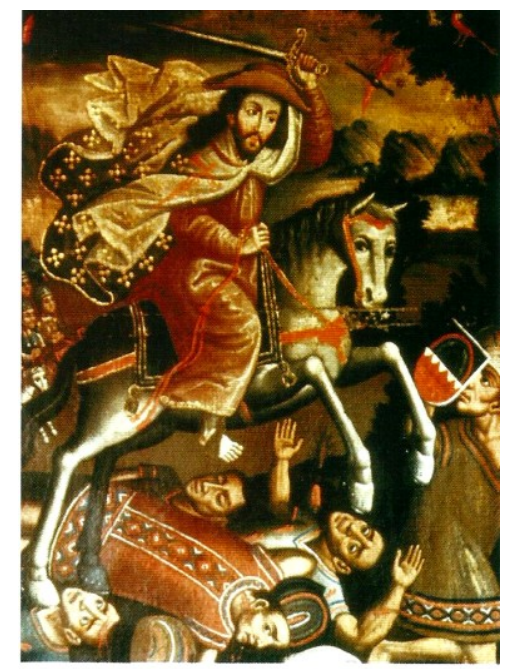

Santiago Mata-indios. Lienzo anónimo, Museo del Cuzco.

Fuente: Gisbert (2007:36). 


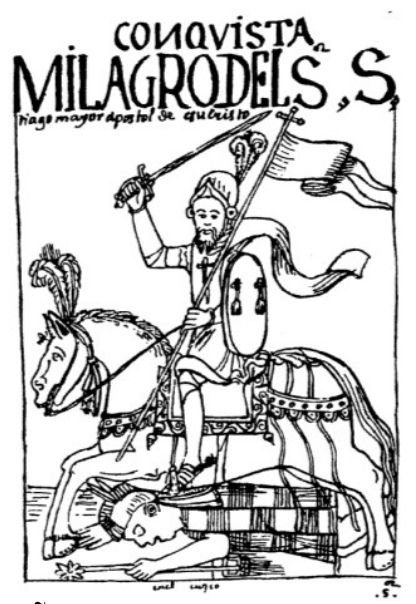

MILAGRO DEL S[EÑ]OR S[an] tiago mayor, apóstol de Jesucristo l en el Cuzco / CONQVISTA, imagen 404 [406].

Fuente: Guamán Poma de Ayala (1615).

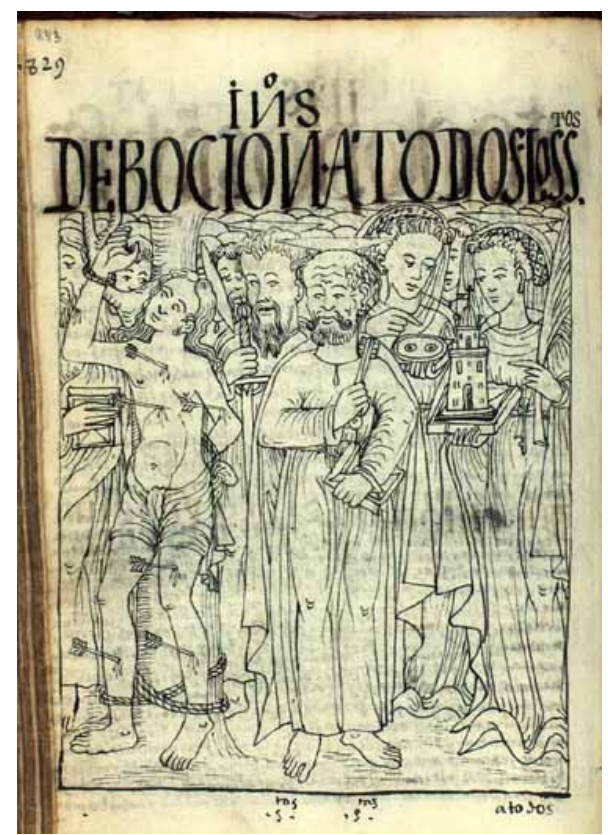

DEBOCIÓN A TODOS LOS S[AN]TOS / santos, santas / IN[DI]OS, imagen 829 [843].

Fuente: Guamán Poma de Ayala (1615). 
Santos patronos en los Andes. Imagen, símbolo y ritual en las fiestas religiosas

\section{LA FIESTA DEL SANTO COMO ESCENA}

Para comprender la eficacia de la imagen debemos volver a lo que subrayamos en los inicios de este texto: la devoción a los santos estaba arraigada entre los campesinos europeos. De hecho, la fiesta patronal en la España del siglo XVI era celebrada en todos los rincones de la península de la siguiente manera:

Las fiestas estaban organizadas de ordinario por las cofradías encargadas y comenzaban con el canto de las vísperas en la tarde anterior. En el día de la fiesta había siempre misa solemne, y en ocasiones sermón y procesión con la imagen del santo o santa. Después de los actos litúrgicos, la gente se divertía con sus "yantares y convites", con sus mascaradas y representaciones, con bailes y danzas (Sánchez, 1978:264-265; citado en Marzal, 1983:264).

La riqueza de la actividad ritual que suscitaba la imagen de los santos, ejemplificada fastuosamente en el despliegue procesional, permite constatar la relevancia de los símbolos sagrados en la tradición católica europea. Es la especificidad de la operación ritual de estas figuras la que permite comprender su eficacia simbólica. Según Delgado:

Aquellas imágenes pintadas o esculpidas de los santos, de la Virgen o del propio Cristo no se conformaban con figurar los personajes del panteón católico, sino que habían sido elevadas a la condición de auténticos objetos poseídos por sus originales redivivos, o cuanto menos a prolongaciones físicas singularizadas de los propios personajes invisibles a quienes aludía. Se trataba de verdaderas presencias vivas, y era de tal mérito maravilloso de donde procedía la capacidad para operar portentos que le era supuesta (Delgado, 1997:373).

A similares conclusiones arribó Huizinga, al argumentar que la operación del pensamiento simbólico en la tradición popular religiosa católica no operaba simplemente uniendo o estableciendo una relación causal entre el significante y el significado de todo simbolismo, sino que funcionaba como una especie de "salto" que sintetiza a ambas (Huizinga, 1990:21). Es en el mismo sentido que, planteamos que los santos operan como verdaderos iconos. No se trata de meras imágenes ni representaciones, pues desbordan claramente su voluntad de mímesis; tampoco operan como meras metáforas, pues no se proponen representar el carácter representativo del objeto a través de un paralelismo con otra entidad. Como ya señalamos, el portentoso signo católico de los santos es una radicalización de la iconicidad del mismo, pues su peculiaridad radica en que, efectivamente, no representa meramente lo que significa, sino que lo ejecuta.

Pero la eficacia del santo como símbolo sagrado sólo puede ser entendida en su máxima manifestación como fruto y eje articulador de un rito. En términos concretos, su figura focaliza y centraliza la atención en el rito. Es el santo el que, en última instancia, permite canalizar la sobreabundancia de prácticas e 


\section{Alberto Díaz, Luis Galdames, Wilson Muñoz}

interpretaciones simbólicas vertidas en el seno de $s u$ celebración, llevando al extremo la ejecución de su eficacia simbólica. De allí, podríamos decir también, la importancia pedagógica de la celebración de estos ritos y de sus performance.

Como exponíamos, a partir de los tiempos litúrgicos y santorales la Iglesia replicó en los Andes las ceremonias ajustadas a los cánones, siendo muchísimas las fiestas que el Tercer Concilio obligaba a los indios a guardar (Vargas Ugarte, 1951:365366). Y si bien en las primeras décadas de la Conquista no existieron acciones concertadas para propagar el catolicismo, la puesta en escena de múltiples prácticas piadosas como celebrar misas, culto a Cristo, María y los santos, la edificación de templos, capillas u oratorios, y el recorrido por las aldeas de la procesión de Semana Santa o de Corpus Christi donde participaron españoles, indios y negros; fueron reproduciendo una cultura religiosa popular y construyendo una religiosidad en el mundo andino (Albó, 2002; Marzal, 2002). Es decir, fue esta constelación de actividades rituales la que se constituyó en el nervio de la evangelización.

Asimismo, los autos sacramentales que representaban escenas bíblicas o milagros de los santos se implementaron como módulos que apelaban a la solemnidad de los actos, escenas y repertorios catequéticos. En tal escenario, los indios debían, por ejemplo, utilizar los atuendos que el culto requería y proceder en conformidad con la sacralidad de dichos actos. De la misma forma, se les solicitaba que:

en los tiempos, que se hacen las procesiones solemnes de Corpus Christi, y en los días de semana sancta y en qualquiera otro tiempo que huviere públicas processiones ninguna mujer ande por las calles, ni esté a las ventanas tapado el rostro, y esto se les manda sopena de excomunicón, y en que incurran ipso facto, pues no es razón que por la livianidad de mujeres se distraiga el pueblo, y aparte del culto divino, antes con la honestidad y decencia de su traje y modestia de su rostro procuren mostrar la fe y devoción interior, y a las justicias y ministros de la república avisamos y exortamos en el señor que, para que se hagan las dichas processiones con más orden y devoción procuren por todas vías que no vayan mezclados y revueltos hombres y mujeres, sino que los hombres vayan todos adelante y las mujeres aparte (como enseña el propheta), sigan a los ministros de la iglesia (Vargas Ugarte, 1951:332).

En la España del siglo XV, la fiesta del Corpus era un evento que celebraba el triunfo del Señor sobre el demonio, erigiéndose como una señal de bendición para los aldeanos. Dicha festividad contenía en su repertorio un acto procesional que recorría las calles de las ciudades o pueblos llevando el Santísimo Sacramento. Los pobladores acudían a vitorear a Cristo consagrado con instrumentos musicales, trajes coloridos y danzas, siguiendo la columna con los santos en andas y las cofradías (García 1989). En el Perú colonial también se decoraban las andas para la procesión sacramental, colocando las imágenes 
de Nuestro Señor o Nuestra Señora o de otro santo o santa de la devoción del español o de los indios sus vasallos. Semejaban las andas a las que en España llevan las cofradías en tales fiestas. Los caciques de todo el distrito de aquella gran ciudad (Cusco) venían a ella a solemnizar la fiesta, acompañados de sus parientes y de toda la gente noble de sus provincias. Traían todas las galas, ornamentos e invenciones que en tiempos de sus reyes Incas usaban en la celebración de sus mayores fiestas (...) Unos venían vestidos con la piel del león... otros traían las alas de un ave muy grande que llaman cuntir... Y así venían otros con otras divisas pintadas, como fuentes, ríos, lagos, sierras, montes, cuevas, porque decían que sus primeros padres salieron de aquellas cosas. Traían otras divisas extrañas, con los vestidos chapados de oro y plata (...) Con las cosas dichas... solemnizaban aquellos indios las fiestas de sus reyes, con las mismas... celebraban en mis tiempos las fiestas del Santísimo Sacramento... como gente de ya desengañada de su gentilidad pasada. (...) Hacían un entablado en la plaza, donde ponían el Santísimo Sacramento en una muy rica custodia (...) Los indios de cada repartimiento pasaban con sus andas, con toda su parentela y acompañamiento, cantando cada provincia en su propia lengua particular materna (...). Llevaban sus atambores, flautas, caracoles y otros instrumentos rústicos musicales. Muchas provincias llevaban sus mujeres en pos de los varones, que les ayudaban a tañer y cantar (Garcilaso de la Vega, 1960:185-186).

La imagen que nos ofrece Garcilaso es vigorosa, pues sintetiza la devoción ante las imágenes durante las procesiones. Por un lado, muestra cómo se fueron insertando la piedad religiosa católica entre los indios, proyectando fehacientes de la eficacia de sus dispositivos catequéticos. Por otro lado, no sólo representan las galas y ornamentos que los indígenas portaban en la procesión, sino que evidenciaban la ceremonialidad del acto, además de la especificidad de sus performances, escenificando la recepción y reconstrucción del imaginario católico desde un horizonte cultural propio, aunque no único. El desfile de trajes emulando el orden sagrado andino, los cánticos realizados en lenguas vernáculas y la peculiaridad de los instrumentos musicales autóctonos operando articuladamente en las procesiones apuntan en este sentido. De manera que, sobre una genérica homología en torno a la escena sacramental, se desarrollaron una serie de especificaciones que evidencian la agencia ritual, apareciendo entonces como un fenómeno emergente en la cultura religiosa colonial.

El relato de Garcilaso se complementa con los escritos de Cobo, quien a mediados del siglo XVII describe la fiesta de Corpus Christi en el altiplano del Collao, zona donde:

es muy de ver las muchas y de veras danzas que sacan en la procesión del Santísimo Sacramento y en otras fiestas grandes. Hallándome yo una vez en un pueblo de la provincia del Collao a la procesión del Corpus Christi, conté en ella cuarenta danzas destas, diferentes unas de otras, que imitaban el traje, 


\section{Alberto Díaz, Luis Galdames, Wilson Muñoz}

cantar y modo de bailar, las naciones de indios cuyas eran propias (Cobo, 1964:270).

Ante el asombro del cronista, la escenificación y despliegue coreográfico de las danzas autóctonas durante la procesión del Corpus reafirma la reedición del proceso de recepción de la cultura católica, la que encontró en los ritos uno de los terrenos más fértiles para su desarrollo. Esto no resulta casual. Y es que los formatos evangelizadores consideraron a la piedad popular como un componente para la propagación de la fe entre la gentilidad andina. Las danzas y cánticos de los indios en honor al Santísimo Sacramento fueron parte de una arquitectura religiosa colonial reconfigurada en la praxis de la piedad popular andina, generando una devoción en torno a los símbolos católicos, como se evidencia en la custodia u ostensorio o el culto a las imágenes al interior de los templos.

Para 1551 el maestro del coro de la Catedral del Cuzco compuso un cántico en honor al Corpus Christi, en un formato musical de:

Chanzotena en canto de órgano, para la fiesta del santísimo Sacramento, contraecha muy al natural al canto de los Incas. Salieron ocho muchachos mestizos, de mis condiscípulos, vestidos como indios, con sendos arados en las manos, con que representaron la procesión el cantar y el haylli de los indios, ayudándoles toda la capilla al retruécano de las coplas, con gran contento de los españoles y suma alegría de los indios, de ver con sus cantos y bailes solenizasen los españoles la fiesta del Señor Dios Nuestro (Garcilaso de la Vega, 1960:151).

Siguiendo este entramado, el fraile agustino Calancha señaló que durante las fiestas patronales:

Tenían los indios prevenida y bien adornada la plaza con arcos de flores, verde juncia y diversos ramos, y acompañaban la procesión con danzas y varios géneros de instrumentos músicos que hicieron más alegre y festivo el día (Calancha, 1972:383).

Como ya hemos consignado, los indígenas solemnizaban las eucaristías o la liturgia utilizando melodías o estructuras sonoras tradicionales andinas, como lo constituían los taki, haylli o los versos en coplas, acompañándose de tambores y quenas. También ensamblaban los compases musicales de los coros en las capillas, donde el órgano era el instrumento principal, aunque también se utilizaban arpas y guitarras (Díaz, 2011; Marzal, 2002). Todo ello fue un recurso agencial utilizado durante el despliegue musical y estético de los dispositivos catequéticos. Al respecto, Oré sugería tener cantores en las capillas que se hicieran acompañar de flautas y chirimías con el objetivo de convertir a los indios y lograr la "confirmación en la fe católica que han recibido de la Santa Iglesia Romana" (Oré 1598:67). La lectura del clérigo deja traslucir la lógica que permitió posicionar las expresiones religiosas en el centro de la devoción popular. 
Los instrumentos musicales y las danzas armonizadas y revestidas en trajes multicolores por los indígenas fueron motivo de investigaciones durante las campañas de extirpación de idolatrías en los albores del siglo XVII, ya que al parecer contenían la invocación a las antiguas wakas o deidades prehispánicas, según la versión de los curas extirpadores (Acosta, 1979:275). Pese a los mecanismos de supresión desplegados por la Curia, las ceremonias constituyeron eventos donde se entrelazaron símbolos católicos propagados desde la catequesis colonial con representaciones e imaginarios indígenas que, entre cánticos y danzas nativas, escenificaron la ritualidad católica al interior de las comarcas andinas. De hecho, hacia 1620, el carmelita Antonio Vásquez de Espinoza advirtió sorprendido que en el Virreinato peruano se celebraban las fiestas incluso con la misma pomposidad que la feligresía y el clero europeo, mostrando que en las festividades paulatinamente se estaban articulando las poblaciones andinas. ${ }^{2}$

\section{De Santo en Santo. Algunas Reflexiones}

En términos generales, las fiestas patronales pueden ser concebidas como ritos comunitarios que involucran una serie de prácticas y una variada disposición de símbolos asociados a los ritos sagrados. Para que el ritual y la fiesta se inscriban en la vida social, los participantes del rito deben imitar y repetir la ejecución de aquellas circunstancias que rememoran: el nacimiento o la muerte de la figura sagrada del santo (incluido Cristo y la Virgen). El rito aparece como una forma de comunicación religiosa orientada a la escenificación colectiva, pues es necesario actuar y representar (danzar y cantar para el caso andino) ritualmente aquello que de lo contrario no podría acontecer, la irrupción de lo sacro en la festividad.

El relativo éxito de estas operaciones rituales es posible gracias a la eficacia del simbolismo que se despliega en su seno: la figura del santo. En tal sentido, los ritos aparecen como uno de los escenarios principales donde se materializa la simbolización, por ello pueden ser entendidos como formas de comunicación que generan sistemas de información redundante, donde a través de diversos canales de distinta naturaleza sensorial (verbal, musical, coreográfico, estético-visual, etc.) se envía información referida a un simbolismo central (Leach, 1989:51-52). A través de esta operación, el ritual maximiza la dimensión performativa de la

\footnotetext{
${ }^{2}$ Tal como manifiesta: "la religión Real de nuestra Señora de la Merced va acabando sumptuosa iglesia, y es su capilla mayor la mejor de todos los conuentos, su primer claustro es excelente, tratan con gran cuidado de estudios, tiene auentajados sujetos, y predicadores, y su agrado es tal que se lleuan la ciudad, por que les vale la sacristian cadaaño mas de 20,000 pezos. Este conuento, y todos los de la ciudad tienen grandes rentas, a que ayudan mucho las dotrinas, e que ocupan los prelados muchos sujetos: celebran sus fiestas solemnissimamente en especial el día de la Natividad de nuestra Señora que sin hazer agrauio, pueden competir con todas las religiones, que quitan el deseo de ver las maiores solemnidades de Roma o de Toledo, o Seuilla, porque la magnificencia, y ostentación es tanta que iguala a qualquier encarecimiento" (Vázquez de Espinosa, 1948:406).
} 


\section{Alberto Díaz, Luis Galdames, Wilson Muñoz}

comunicación. Es por ello que los símbolos utilizados en estos contextos son efectivos, llegando a activar transformaciones en distintos ámbitos de la vida social, como el contexto espacio/temporal, la comunicación y las personas involucradas.

Si bien al interior del rito emergen múltiples símbolos, para efectos de este trabajo resulta particularmente atractivo comprender la figura del santo como un símbolo dominante, debido a sus significativas peculiaridades. Según Turner, este símbolo tiende a transformarse en un factor de acción social en el rito, pues la comunidad profesa su culto, convirtiéndose en un centro neurálgico de interacción social (Turner, 1973:19). Esto es lo que ocurriría efectivamente con la imagen sagrada del santo patrono que encabeza la procesión y otras ceremonias. En medio de su escenificación, se manifiesta la excitación social y se estimula a los participantes a través de la música, los cantos, los bailes, diversos consumos como la chicha, que suelen referirse de alguna forma (directa o indirectamente) a este símbolo sagrado, amplificando con ello la comunicación e interacción referida a él. Unido ello, estos símbolos poseen una especial capacidad para "golpear" directamente a los participantes, expandiendo su cualidad emocional a las conductas y la situación en general. Por último, poseen la capacidad de condenar diversos significados en la actividad ritual. Es decir, dada su centralidad focal dentro de las interacciones rituales y su capacidad tanto de promover como de condensar significados diversos, el símbolo dominante es altamente efectivo en escenarios rituales.

Ahora bien, esta primera caracterización genérica de la operación del símbolo dominante del santo en el ritual requiere una segunda especificación. Los símbolos religiosos pueden concebirse como una distinción entre significante y significado, una suerte de bisagra simbólica. En el caso del santo, a través de su imagen santoral se visibilizaría lo sacro (invisibilizado), dejando abierta a interpretaciones aquella referencia a lo trascendente desplegada en la festividad popular. Así, el santo refleja en su imagen física la connotación religiosa que la comunidad andina ha construido en torno a su fe desde la época colonial, evidenciando la relación que se mantiene entre lo sagrado y lo profano. Bajo esta perspectiva, es dable comprender cómo el uso popular de la religión es modificado de acuerdo a las realidades locales, reorientando los significados catequéticos emanados desde la Curia para resignificarlos mediante usos locales implicados en la festividad, pues el significado último al que remite el santo queda abierto a las reinterpretaciones comunitarias.

Pareciera ser que en el caso del santo la frontera simbólica entre significante y significado tiende a anularse, funcionando ritualmente más bien como un icono, según la expresión de Peirce (1979:24). El santo maximizaría su iconicidad, pues con su imagen no sólo nos envía o remite simbólicamente a un segundo plano que nos entrega un significado sacro, el cual es interpretado en clave cultural, sino que su peculiaridad es que su imagen es también el santo en sí mismo. Es por ello que la 
distancia ente significante y significado en cierta forma eclosiona, pues la representación de lo sacro confluye con lo sacro. Esto admitiría entender por qué durante la festividad las imágenes de los santos son tratadas como si fueran seres existentes, humanizándolas, siendo incluso vestidas, adornadas, cuidadas, vitoreadas, etc. Y, quizás, el acto que de manera más explícita manifiesta esta propiedad humano-vital de las imágenes sagradas sea la procesión que hemos identificado en las crónicas coloniales. Mediante todo el despliegue ritual realmente se re-vive su ser, como si a través de estas pomposas procesiones el santo estuviera realmente presente en la fiesta y literalmente "anduviera" por las calles del pueblo, visitando los distintos lugares que sacraliza a su paso. Es en este sentido que la performatividad de la escenificación ritual es llevada a su extremo en el caso del icono del santo patrono.

Tal como hemos expuesto en este artículo, la dimensión simbólico-ritual propia de la celebración a los santos patronos es un fenómeno emergente. Si bien no desconocemos sus condiciones de posibilidad, consideramos que posee una especificidad que no obedece únicamente a ellas. Es la especificidad de las operaciones de los mecanismos simbólicos articulados por y en torno a el santo en un contexto ritual propio de esta festividad, lo que permite comprender de manera más concreta el éxito de esta celebración en el mundo andino.

En torno a la iconografía de Cristo, la Virgen y los santos, se presenta como un dispositivo cultural que maximiza la dimensión performativa en su despliegue en escena, llevando con ello al extremo la eficacia simbólica del santo: el santo está $a h i$, acontece en la festividad, manifestándose casi directamente a los fieles. Todo el tratamiento que reciben estas imágenes expresa de manera clara este hecho. Quizá por ello el franciscano Oré confiaba tanto en que la instalación de imágenes en los templos y la celebración de diversas festividades unida a ello serían un mecanismo efectivo para promover la devoción popular en el área andina. Es la naturaleza del santo-ícono desplegada de manera predilecta en la escenificación ritual la que realmente hace efectiva esta situación.

Sintetizando, lo anterior nos permite dilucidar cómo el icono del santo ofrece, por su propia naturaleza, la apertura a la reinterpretación local. Si consideramos que el simbolismo del santo es realmente una distinción que opera como una frontera simbólica (significante/significado), se comprende entonces que el significado al que remite su manifestación está abierto a las resemantizaciones, inventivas y a las configuraciones rituales agenciadas por la comunidad local, las que tanto asombraron a los cronistas al observar las procesiones de los indígenas a Corpus Christi. Siguiendo la estructura del canon católico supuesto para las festividades religiosas, los indígenas escenificaban su actividad cúltica practicando sus taki, ritmificados por sus instrumentos autóctonos, coreografías diversas y coloreados atuendos ofrecidos como parte del repertorio devocional a las imágenes de los santos durante el tiempo sagrado de la fiesta patronal. 
Alberto Díaz, Luis Galdames, Wilson Muñoz

Universidad de Tarapacá*

Departamento de Ciencias Históricas y Geográficas

albertodiaz@uta.cl

Universidad de Tarapacá**

Departamento de Ciencias Históricas y Geográficas

lgaldame@uta.cl

Universidad de Tarapacá***

Departamento de Ciencias Históricas y Geográficas

wilsonsocio@gmail.com

\section{BIBLIOGRAFÍA}

Acosta, Joseph de. Historia Natural y Moral de las Indias. México: Fondo de Cultura Económica, 1979.

Albó, Xavier. "Preguntas para los historiadores desde los ritos andinos actuales", en Jean-Jaques Decoster (ed.). Incas e indios cristianos. Elites indígenas e identidades cristianas en los Andes coloniales. Cusco: Centro de Estudios Regionales Andinos Bartolomé de Las Casas, IFEA, Asociación Kuraka, 2002.

Anónimo (Jesuita). Relación de las costumbres antiguas de los naturales del Peru, tomo 209, Crónicas Peruanas de Interés Indigena. Madrid: Ediciones Atlas, 1968:151-189.

Bajtin, Mijail. La cultura popular en la Edad Media y en el Renacimiento. El contexto de Francois Rabelais. Madrid: Alianza, 2002.

Calancha, Antonio de la. Crónicas agustinianas del Perú. Vol. XVII. Madrid: Consejo Superior de Investigaciones Científicas, 1972.

Cobo, Bernabé. Historia del nuevo mundo. B.A.E. Madrid: Atlas, 1964.

Delgado, Manuel. "Exorcismo y martirio de las imágenes. La iconoclastia como violencia corporal en las sociedades mediterráneas", en Checa, F. y Molina, P. (eds.). La función simbólica de los ritos. Rituales y simbolismo en el Mediterráneo, Barcelona: Icaria / ICA, 1997:367-398.

Díaz Araya, Alberto. Fiesta patronal y sistema de cargos religiosos en el norte de Chile. Tesis para optar al grado de Doctor en Antropología. San Pedro de Atacama: Universidad Católica del Norte, 2011.

Estenssoro, Juan Carlos. El simio de Dios. Los indígenas y la iglesia frente a la Evangelización del Perú, siglos XVI y XVII. Bulletin de l'Institut francais d'études Andins, Volume: 30; 2001.

Estenssoro, Juan Carlos. Los Bailes de los Indios y el Proyecto Colonial, en Revista Andina Año 10, № 2, 1992.

García, José. "Los Bailes Religiosos del norte de Chile o los Danzantes de la Virgen". Santiago: Seminario Pontificio Mayor de los Santos Ángeles Custodios, 1989. 
Santos patronos en los Andes. Imagen, símbolo y ritual en las fiestas religiosas

Garcilaso de la Vega, Inca. Segunda parte de los Comentarios reales de los Incas. Buenos Aires: Emecé, 1960.

Gisbert, Teresa. La fiesta en el tiempo. La Paz: Unión Latina, 2007.

Guamán, Poma de Ayala, Felipe. El primer Nueva Coronica y Buen Gobierno. México: Siglo XXI, 1615-1992.

Heras, Julián. Los franciscanos en el valle de Codpa (Arequipa). Dos siglos y medio de evangelización (1540-1790), 1990.

Leach, Edmund. Cultura y comunicación. La lógica de la conexión de los símbolos. Madrid: Siglo XXI, 1989.

Marzal, Manuel. La transformación religiosa peruana. Lima: Pontifica Universidad Católica del Perú, 1983.

Marzal, Manuel. "Los 'santos' y la transformación religiosa del Perú colonial”, en Jean-Jaques Decoster (ed.). Incas e indios cristianos. Elites indígenas e identidades cristianas en los Andes coloniales. Cusco: Centro de Estudios Regionales Andinos Bartolomé de Las Casas, IFEA, Asociación Kuraka, 2002.

Mateos, Francisco de. Historia de la Compañía de Jesús. Madrid: Consejo Superior de Investigaciones Científicas, 1944.

Millones, Luis. Ensayos de historia andina. Lima: Fondo Editorial de la Facultad de Ciencias Sociales, 2005.

Millones, Luis. Taki Onqoy: De la enfermedad del canto a la epidemia. Santiago de Chile. Centro de investigaciones Diego Barros Arana, 2007.

Oré, Jerónimo de. Symbolo catholico indiano. Lima, 1598.

Peirce, Charles. La ciencia de la semiótica. Buenos Aires: Nueva Visión, 1979.

Turner, Víctor. Simbolismo y ritual. Lima: Pontificia Universidad Católica del Perú, 1973.

Urbano, Enrique. Catolicismo y Extirpación de Idolatrías. Siglos XVI - XVIII. Cusco: Centro de estudios Regionales Andinos Bartolomé de Las Casas, 1993.

Vargas Ugarte, Rubén. Concilios Limenses (1551 - 1772). Lima, 1951.

Vázquez de Espinosa, Antonio. Compendio y Descripción de las Indias Occidentales. Washington: Smithsonian Miscellaneous Collections, 1948.

Villena, Marcelo. "El discurso encanto de la eucaristía, una experiencia con el "3er. Catecismo o Sermonario" del 3er. Concilio Limense (1584-1585)", en Estudios Bolivianos, 9, 2001:123-125. 